\title{
TIPOLOGI SEBARAN PERILAKU PEMBAKARAN LAHAN GAMBUT DI KABUPATEN KUBU RAYA DAN KABUPATEN BENGKAYANG PROVINSI KALIMANTAN BARAT
}

\author{
Maswadi ${ }^{1)}$, Maulidi ${ }^{1}$, Wanti Fitrianti ${ }^{1}$, , Shenny Oktoriana ${ }^{1}$, Rini Hazriani ${ }^{1)}$, Dwi \\ Raharjo ${ }^{1)}$, Dwi Zulfita ${ }^{1)}$, Ari Krisno Hadi ${ }^{1}$, Kuno Hiromitsu ${ }^{2)}$, Anna Syilviana Kartika ${ }^{3)}$, \\ Sahat Irawan Manik ${ }^{4)}$ \\ 1) Dosen Fakultas Pertanian Universitas Tanjungpura Pontianak \\ 2) Program of Community Development of Fires Control in Peat Land Area (FCP) \\ (Kementerian Kehutanan-Japan International Cooperation Agency /JICA) \\ 3) Direktorat Pengendalian Kebakaran Hutan, Ditjen PHKA, Kementerian Kehutanan \\ 4) Balai Konservasi Sumber Daya Alam Kalimantan Barat, Kementerian Kehutanan
}

\begin{abstract}
The purpose of this study was to analyze (1) the correlation of factors that affect the spread of forest fire indication, and (2) the pattern of distribution, land burning time, and the public perception of combustion in Kubu Raya and Bengkayang Districts. The research activities were carried out in 12 villages in Kubu Raya and Bengkayang Districts during the month of November 2014 until January 2014. The research method is using correlation analysis and descriptive to explain the distribution patterns, land burn time, and the public perception of combustion. The results showed: 1) there is a relationship between the purpose of combustion (open land and eradicate weeds) with the population, and there is no relationship between the objectives of land combustion on the combustion behavior of the land associated with the main types of cultivated plants, and there is a correlation to the density of hotspots, the density of dry land farming and bush, shrub/ swamp density, marsh density, density of plantation, and density of open land. 2) The pattern of the farmers burning rice, horticulture and perenninal crops were classified into the type of the pattern of spots and the perception is part of a burning activities, type with ash beds and lodge with the perception of not being a part of burning activities, and type with only one time burning on the stages of land preparation, and type with in the eradication of weeds.
\end{abstract}

Keywords: Peat fires, Land burning behavior, Climate Change Mitigation

\section{PENDAHULUAN}

Kebakaran lahan dan hutan pada daerah lahan gambut di Provinsi Kalimantan Barat merupakan peristiwa yang terjadi rutin hampir setiap tahun. Faktor utama penyebab kebakaran lahan selama ini adalah perilaku manusia dalam pemanfaatan lahan, walaupun kondisi iklim dan lingkungan memperbesar kemungkinan dan intensitas kebakaran. Dengan demikian pada sisi yang lain, peran manusia dapat menjadi faktor terpenting dalam upaya pencegahan kebakaran gambut apabila manajemen pengelolaan lahan dilakukan menurut kaidah dan norma-norma yang ramah lingkungan.

Pengelolaan lahan gambut yang berwawasan lingkungan sangat perlu dipraktekkan mengingat lahan gambut merupakan salah satu lahan untuk masa depan apabila diusahakan dengan cara pengelolaan yang tepat (Leiwakabessy,F.M. dan M.Wahjudin,1979) . Persepsi petani terhadap lahan gambut sangat terbatas sehingga usaha-usaha konservasi untuk mempertahankan produktivitas lahan gambut juga terbatas. Berbagai permasalahan banyak dihadapi petani di sekitar lahan gambut. Masalah peningkatan kondisi sosial ekonomi dan pemanfaatan sumber daya ekonomi menjadi masalah utama yang belum bisa diselesaikan hingga saat ini. 
Berdasarkan latar belakang dan uraian diatas maka penelitian ini secara khusus bertujuan (1) menganalisis korelasi faktor-faktor yang mempengaruhi sebaran indikasi kebakaran hutan dan lahan, dan (2) menganalisis pola sebaran, waktu bakar lahan serta persepsi bakar masyarakat di Kabupaten Kubu Raya dan Kabupaten Bengkayang.

\section{METODE PENELITIAN}

Kegiatan penelitian ini dilaksanakan di 12 desa yang tersebar di Kabupaten Kubu Raya dan Kabupaten Bengkayang. Desa-desa sebagai lokasi survey antara lain Rasau Jaya umum, Bintang Mas, Punggur Kecil, Punggur Besar, Kuala Dua, Tebang Kacang, Sungai Raya Dalam, Arang Limbung, untuk wilayah Kabupaten Kubu Raya sedangkan Karimunting, Sungai Raya, Sungai duri, Desa Sungai jaga A untuk wilayah desa Kabupaten Bengkayang. Kegiatan penelitian ini dilaksanakan selama November 2014 hingga Januari 2014.

Penentuan sampel responden dalam kegiatan survey dilakukan melalui 2 tahap, yaitu penentuan sampel desa pada masing-masing kabupaten, kemudian yang terakhir menentukan sampel responden dari setiap dusun atau RW/RT yang telah ditentukan. Penentuan jumlah sampel rumah tangga digunakan rumus Slovin (Umar, 2000). Adapun jumlah sampel untuk tiap desa pada kisaran 61-69 responden.

Untuk menjawab tujuan 1 dilakukan analisis dengan menggunakan analisis korelasi. Selanjutnya untuk tujuan 2 menggunakan analisis deskriptif untuk menjelaskan pola sebaran, waktu bakar lahan serta persepsi bakar masyarakat di Kabupaten Kubu Raya dan Kabupaten Bengkayang.

\section{HASIL DAN PEMBAHASAN}

\section{Sebaran Indikasi Kebakaran Hutan dan Lahan}

Secara umum terjadinya kebakaran hutan di hutan rawa gambut disebabkan oleh faktor manusia, baik disengaja maupun tidak ada kesengajaan. Kebakaran hutan rawa gambut dapat terjadi secara periodik terutama pada musim kemarau panjang. Sumber api sebagian besar berasal dari aktivitas manusia pada hutan tersebut, yakni dapat berupa penyiapan lahan untuk berladang dengan sistem tebas, tebang, dan bakar Padahal kebakaran hutan dan lahan gambut dapat mengakibatkan kerusakan yang lebih berat dibandingkan dengan dampak eksploitasi, karena kerusakan yang terjadi akan menurunkan produktivitas lahan serta menurunkan daya dukung lahan dalam menopang pertumbuhan vegetasi di atasnya. Oleh karena itu penting untuk mengetahui hubungan perilaku pembakaran, densitas hotspot dengan faktor yang mempengaruhi kebakaran lahan.

\section{a. Analisis Korelasi Faktor yang Mempengaruhi Perilaku Membakar Lahan}

Hasil analisis prediksi perilaku membakar lahan yang telah dilakukan menunjukkan bahwa :

\section{Korelasi antara Jumlah penduduk desa dengan tujuan membakar lahan}

Terdapat hubungan korelasi antara jumlah responden yang membakar lahan terhadap tujuan membakar untuk membuka lahan pada taraf signifikansi $1 \%$ dan memberantas gulma pada taraf signifikansi $5 \%$. sedangkan dengan tujuan membakar lainnya tidak terdapat korelasi pada taraf signifikansi $5 \%$ seperti terlihat pada Tabel 1 . Hal ini menunjukkan bahwa kebanyakan masyarakat melakukan pembakaran lahan dengan tujuan untuk membuka lahan dan memberantas gulma. Hasil penelitian ini juga 
mendukung penelitian Abdullah, 2002 bahwa faktor manusia yang dapat memicu terjadinya kebakaran meliputi pembukaan lahan dalam rangka pengembangan pertanian berskala besar, persiapan lahan oleh petani, dan kegiatan-kegiatan rekreasi seperti perkemahan, piknik dan perburuan.

Tabel 1. Korelasi Variabel Jumlah Penduduk Desa Terhadap Tujuan Membakar Lahan

\section{Parameter Tujuan Membakar Lahan}

\section{Membuka lahan}

Kesuburan tanah

Memberantas gulma

Membersihkan lahan pasca panen

Sumber : Data primer

\section{Signifikansi}

$<0,0001$
0,902
0,048
0,104

$<0,0001$

0,104

\section{Korelasi Variabel Tujuan Membakar Lahan Terhadap Pelaku Pembakaran Dilihat dari Jenis Tanaman Utama yang Diusahakan}

Berdasarkan Tabel 2 menunjukkan hasil tidak terdapat korelasi antara tujuan membakar lahan terhadap pelaku pembakaran lahan dilihat dari jenis tanaman utama yang diusahakan pada taraf signifikansi $5 \%$. Hal ini mengindikasikan bahwa perilaku pembakaran tidak hanya dilakukan pada tanaman utama tapi juga pada tanaman lain selain tanaman utama.

Tabel 2. Korelasi Variabel Tujuan Membakar Lahan Terhadap Pelaku Pembakaran Dilihat dari Jenis Tanaman Utama yang Diusahakan Responden

\begin{tabular}{lcccc}
\hline \multirow{2}{*}{ Parameter Tujuan Membakar Lahan } & \multicolumn{3}{c}{ Parameter Pelaku Pembakaran } \\
\cline { 2 - 5 } & Petani Padi & $\begin{array}{c}\text { Petani } \\
\text { Palawija }\end{array}$ & $\begin{array}{c}\text { Petani Tanaman } \\
\text { Tahunan }\end{array}$ & $\begin{array}{c}\text { Petani } \\
\text { Hortikultura }\end{array}$ \\
\hline Membuka lahan & 0,482 & 0,659 & 0,415 & 0,668 \\
Kesuburan tanah & 0,970 & 0,126 & 0,892 & 0,822 \\
Memberantas gulma & 0,062 & 0,502 & 0,215 & 0,165 \\
Membersihkan lahan pasca panen & 0,532 & 0,400 & 0,846 & 0,307 \\
\hline
\end{tabular}

Sumber : Data primer

\section{Korelasi antara variabel perilaku pembakaran}

Berdasarkan Tabel 3 menunjukkan bahwa terdapat hubungan korelasi yang signifikan antara variabel-variabel yang menggambarkan perilaku membakar lahan, yang terdiri dari perilaku membakar atau tidak membakar, frekuensi membakar lahan, luas lahan yang dibakar serta tingkat kepedulian terhadap kebakaran lahan. Adapun variabel yang digunakan antara lain luas lahan, penghasilan rumah tangga, kehadiran dalam penyuluhan, persentase krbutuhan modal usaha tani, jumlah jenis tanaman, jumlah petak lahan, persentase luas lahan tanaman tahunan, jumlah lahan yang mengalami masa istirahat, lama bermukim, keaktifan gotong royong, pekerjaan utama, penerapan kearifan lokal, konflik kepemilikan lahan, membakar untuk mengolah lahan dan usaha ekonomi. 
Tabel. 3 Korelasi Variabel Perilaku Pembakaran Tahun Ketiga

\begin{tabular}{lrrrrr}
\hline \multicolumn{1}{c}{ Perilaku Membakar Lahan } & \multicolumn{1}{c}{ Y1 } & \multicolumn{1}{c}{ Y2 } & \multicolumn{2}{c}{ Y4 } \\
\hline Y1 & 1 & .000 & .000 & .000 \\
Y2 & .000 & 1 & .008 & .000 \\
Y3 & .000 & .008 & 1 & .096 \\
Y4 & .000 & .000 & .096 & 1
\end{tabular}

Sumber : Hasil analisis data primer, 2013

Keterangan :

Y1 = perilaku membakar lahan (membakar/tidak membakar)
Y2= Frekuensi membakar lahan
Y3= Luas lahan yang dibakar
Y4= Tingkat kepedulian terhadap kebakaran lahan

\section{b. Analisis Korelasi Densitas Hotspot Terhadap Faktor yang Mempengaruhi Kebakaran Lahan}

Berdasarkan hasil analisis korelasi terhadap faktor penyebab kebakaran lahan ternyata faktor yang memiliki hubungan yang paling erat secara berurutan terhadap densitas hotspot adalah densitas pertanian lahan kering dan semak, desitas belukar/rawa, desitas rawa, densitas perkebunan dan desitas tanah terbuka seperti terlihat pada Gambar 1. Hal ini mengindikasikan daerah yang rawan terhadap kebakaran adalah pada lahan pertanian lahan kering dan semak, belukar/rawa, desitas rawa, densitas perkebunan dan desitas tanah terbuka.

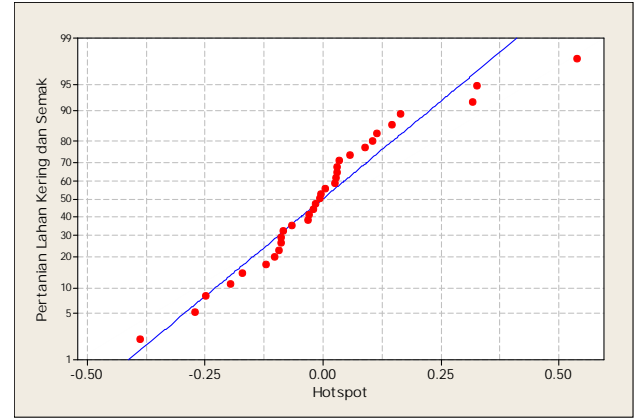

$Y=0,113+0,185 X ; R^{2}=73,4 \%$

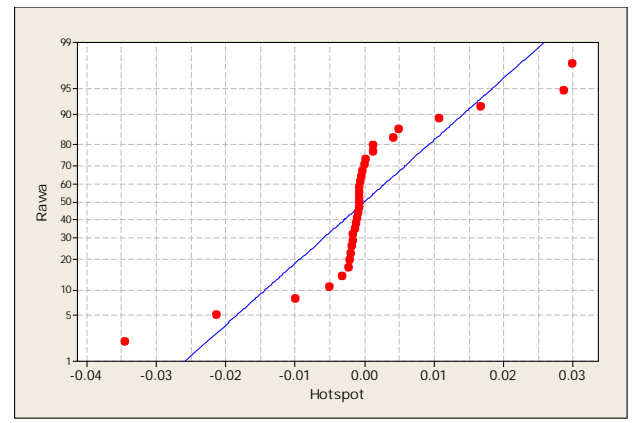

$Y=0,00075+0,00651 X ; R^{2}=46,3 \%$

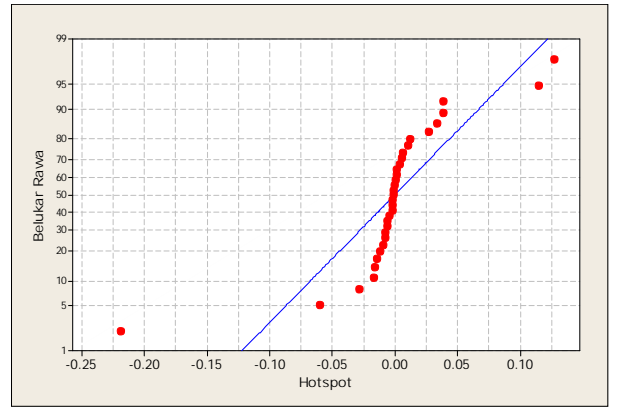

$Y=0,0017+0,0410 X ; R^{2}=60,6 \%$

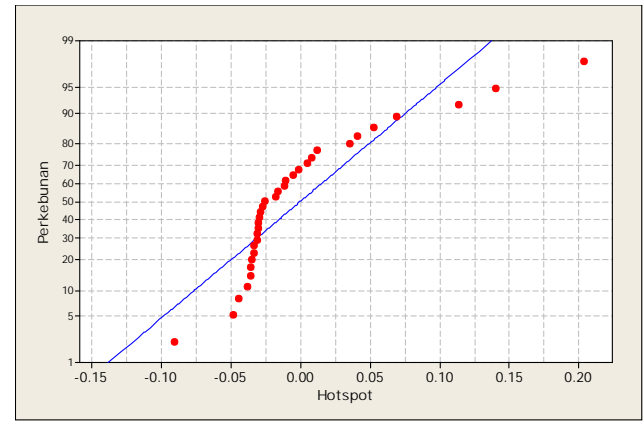

$Y=0,0324+0,0324 X ; R^{2}=42,9 \%$ 


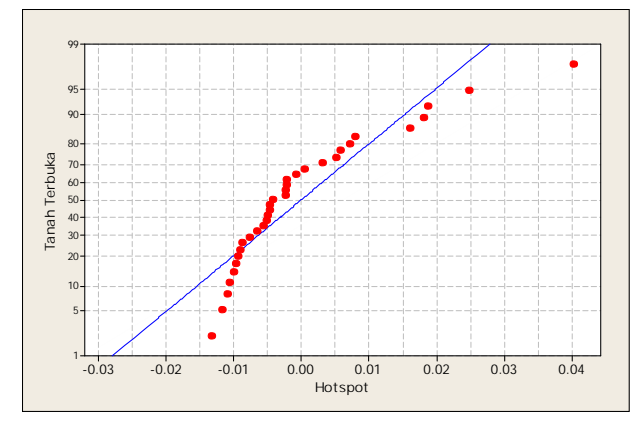

$$
Y=0,0109+0,00611 X ; R^{2}=39,5 \%
$$

Gambar 1. Hasil Analisis Korelasi Densitas Hotspot Terhadap Faktor Penyebab Kebakaran Lahan

\section{Pola Sebaran dan Waktu Bakar Lahan serta Persepsi Bakar Masyarakat di Kabupaten Kubu Raya dan Kabupaten Bengkayang}

Terkait dengan kebakaran lahan di Kabupaten Kubu Raya dan Kabupaten Bengkayang hal tersebut tidak dapat dipisahkan dengan kegiatan pertanian tanaman masyarakat. Hal tersebut mengingat pertanian yang dilakukan pada umumnya masih menggunakan sistem pertanian ekstensif, dengan digunakannya penyiapan lahan dengan cara dibakar baik tanaman padi maupun jagung dan tanaman lainnya Berikut ini akan diuraikan tentang sistem pola sebaran, waktu bakar dan persepsi bakar bagi masyarakat .

\section{a. Pola Bakar, Waktu Bakar dan Persepsi Bakar Tanaman Padi}

Pada dasarnya ada perbedaan pola pembakaran yang dilakukan antara petani padi sawah dan petani padi ladang. Untuk padi sawah di daerah penelitian petani menggunakan 2 jenis bibit yakni lokal dan padi unggul seperti tergambar pada Gambar 2 dan 3. Untuk petani padi lokal dilakukan pembakaran dengan pola spot-spot dengan cara vegetasi ditebas terlebih dahulu, selanjutnya dikumpulkan spot dibeberapa tempat. Biasanya padi lokal ditanam 1x setahun di bulan Agustus. Waktu pembakaran di bulan September hanya 1 kali pada saat persiapan lahan. Persepsi petani dalam perilaku pembakaran yang dilakukan dalam usaha tani padi lokal menurut mereka merupakan wujud dari kegiatan pembakaran lahan.

Pada petani padi unggul melakukan pembakaran dengan cara semak ditebas dan dikumpulkan dalam pondok, lalu dibakar. Biasanya padi unggul ditanam $2 x$ setahun dan dolakukan 2x waktu pembakaran yakni di bulan April dan September pada saat persiapan lahan. Persepsi petani dalam perilaku pembakaran yang dilakukan pada usaha tani padi unggul bagi mereka merupakan tidak menjadi bagian dari kegiatan pembakaran lahan.

Selanjutnya pada petani padi ladang ada 2 tipologi bakar yang dilakukan yakni melakukan pembakaran dengan pola hamparan dan diluar areal tanam untuk penyiangan gulma.

Pertama, Pola hamparan dilakukan dengan cara vegetasi ditebas dan ditebang, dihamparkan pada lahan; kemudian dibakar, jika masih terdapat sisa-sisa vegetasi yang tidak terbakar, dikumpulkan pada beberapa tempat dan dilakukan pembakaran kembali semak ditebas dan dikumpulkan dalam pondok, lalu dibakar. Biasanya padi ladang ditanam 1x setahun dan melakukan 3x waktu pembakaran yakni di bulan Juli pada tahapan persiapan lahan, Oktober dan Desember pada saat penyiangan sisa gulma. Persepsi petani padi ladang dalam perilaku pembakaran dengan pola hamparan yang dilakukan merupakan bagian dari kegiatan pembakaran lahan seperti tersaji pada Gambar 4. 
Kedua, pola pembakaran padi ladang cara semak ditebas, hingga kering; kemudian ditumpuk di luar areal tanam (pepohonan) kemudian dibakar Persepsi petani karet dalam perilaku pembakaran yang dilakukan dengan cara ini bagi mereka bukan/tidak wujud dari kegiatan pembakaran lahan seperti tergambar pada Gambar 5.

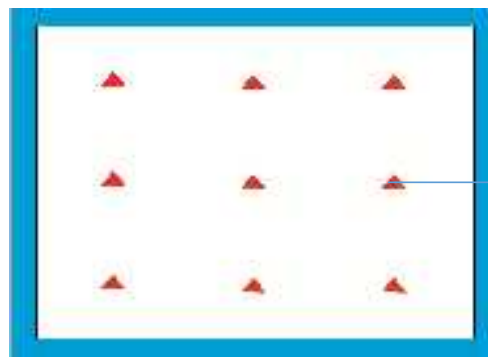

\begin{tabular}{crl}
\hline \multicolumn{2}{c}{ Persepsi Bakar } \\
\hline $\begin{array}{c}\text { Kab. Kubu } \\
\text { Raya }\end{array}$ & \multicolumn{2}{c}{ Kab. } \\
Bengkayang \\
\hline Ya & Tidak & \multicolumn{2}{c}{ Ya } & Tidak \\
\hline$\sqrt{ }$ & & $\sqrt{ }$
\end{tabular}

Gambar 2. Pola Bakar Lahan pada Persiapan Lahan untuk Tanaman Padi Sawah

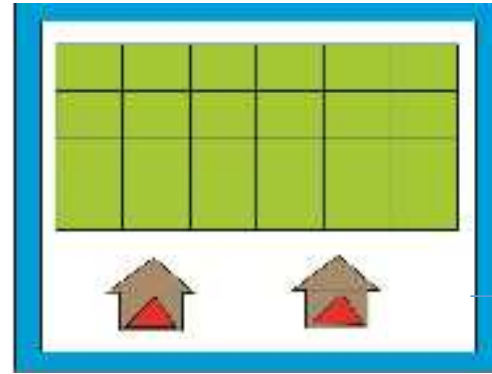

\begin{tabular}{ccc}
\hline \multicolumn{2}{c}{ Persepsi Bakar } \\
\hline $\begin{array}{c}\text { Kab. Kubu } \\
\text { Raya }\end{array}$ & \multicolumn{2}{c}{ Kab. } \\
Bengkayang
\end{tabular}

Pondok bakar

Gambar 3. Pola Bakar Lahan pada Persiapan Lahan untuk Tanaman Padi Sawah
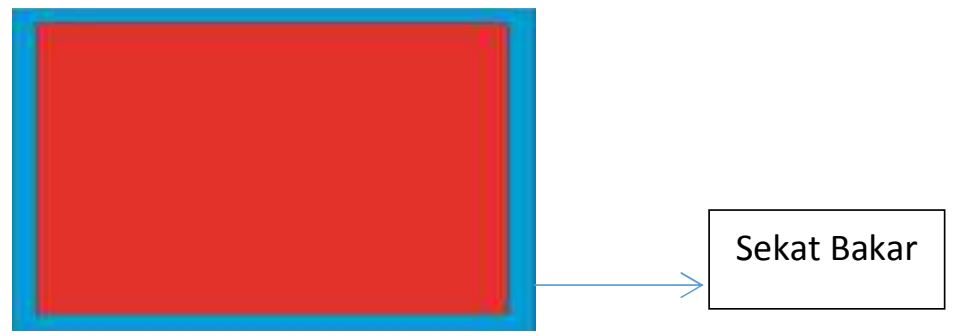

\begin{tabular}{cc|c}
\hline \multicolumn{3}{c}{ Persepsi Bakar } \\
\hline $\begin{array}{c}\text { Kab. Kubu } \\
\text { Raya }\end{array}$ & \multicolumn{2}{c}{ Kab. } \\
Bengkayang \\
\hline Ya & Tidak & \multicolumn{2}{c}{ Ya } & Tidak \\
\hline$\sqrt{ }$ & & $\sqrt{ }$ \\
\end{tabular}

Gambar 4. Pola Bakar Lahan pada Persiapan Lahan Padi Ladang

Spot bakar

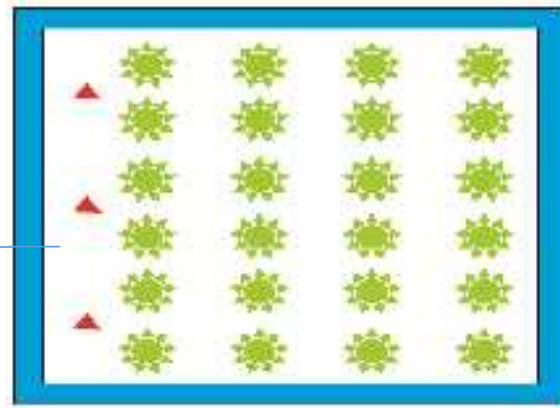

\begin{tabular}{|c|c|}
\hline \multicolumn{2}{|c|}{ Persepsi Bakar } \\
\hline $\begin{array}{c}\text { Kab. Kubu } \\
\text { Raya }\end{array}$ & $\begin{array}{c}\text { Kab. } \\
\text { Bengkayang }\end{array}$ \\
\hline Tidak & Tidak \\
\hline
\end{tabular}

Gambar 2. Pola Bakar Lahan pada Pemeliharaan Tanaman (penyiangan gulma) untuk Tanaman Padi Ladang 


\section{b. Pola Bakar, Waktu Bakar dan Persepsi Bakar Tanaman Palawija}

Pada dasarnya terdapat perbedaan pola pembakaran yang dilakukan pada tanaman palawija (jagung), berdasarkan penelitian ini didapatkan 4 (empat) pola pembakaran petani palawija

Pertama, pola pembakaran pada lahan jagung di tanah gambut dilakukan dengan cara pola hamparan dengan cara membuat sekat bakar dibuat mengelilingi lahan kemudian semak ditebas, dibakar secara merata dalam pengawasan. Persepsi petani dalam perilaku pembakaran yang dilakukan dengan cara hamparan menurut mereka merupakan wujud dari kegiatan pembakaran lahan seperti tergambar pada Gambar 4.

Kedua, pola pembakaran membuat pondok abu dengan cara vegetasi ditebas dikumpulkan di atas bedengan, kemudian dibakar. Setelah itu abu sisa pembakaran disimpan dalam pondok untuk menghindari terkena hujan untuk selanjutnya abu disebar ke lahan sebelum tanam. Persepsi petani dalam perilaku pembakaran yang dilakukan dengan cara ini bukan merupakan wujud dari kegiatan pembakaran lahan seperti tergambar pada Gambar 5.

Ketiga, pola pembakaran dengan pola spot-spot, kemudian vegetasi ditebas, dikumpulkan membuat spot bakar dibeberapa tempat, selanjutnya dibakar. Persepsi petani dalam perilaku pembakaran yang dilakukan dengan cara ini merupakan wujud dari kegiatan pembakaran lahan seperti tergambar pada Gambar 6.

Keempat, pola pembakaran diatas bedengan dengan cara terlebih dahulu vegetasi yang sudah ditebas dikumpulkan di atas bedengan, kemudian dibakar. Persepsi petani dalam perilaku pembakaran yang dilakukan dengan cara ini merupakan bukan wujud dari kegiatan pembakaran lahan seperti tergambar pada Gambar 7.

Secara keseluruhan berdasarkan pola bakar yang dilakukan untuk waktu bakar memiliki keseragaman yakni biasanya tanaman palawija ditanam $2 x$ setahun dengan waktu pembakaran juga dilakukan $2 x$ di bulan Februari dan September pada saat persiapan lahan dan penyiangan gulma.

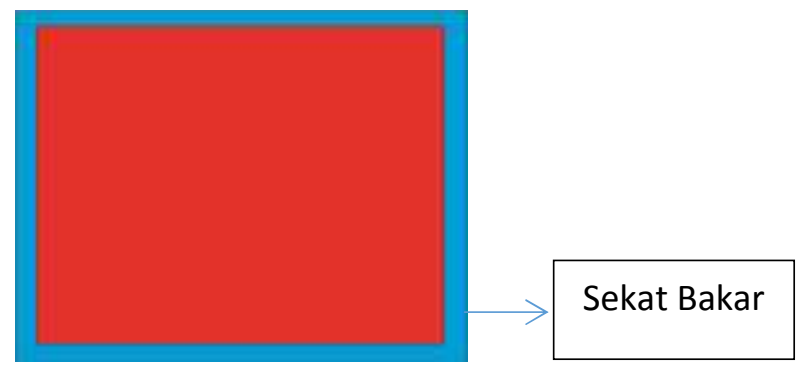

\begin{tabular}{|c|c|}
\hline \multicolumn{2}{|c|}{ Persepsi Bakar } \\
\hline $\begin{array}{l}\text { Kab. Kubu } \\
\text { Raya }\end{array}$ & $\begin{array}{c}\text { Kab. } \\
\text { Bengkayang }\end{array}$ \\
\hline Tidak & Tidak \\
\hline$\sqrt{ }$ & $\sqrt{ }$ \\
\hline
\end{tabular}

Gambar 4. Pola Bakar Lahan pada Persiapan Lahan untuk Tanaman Palawija (Jagung)

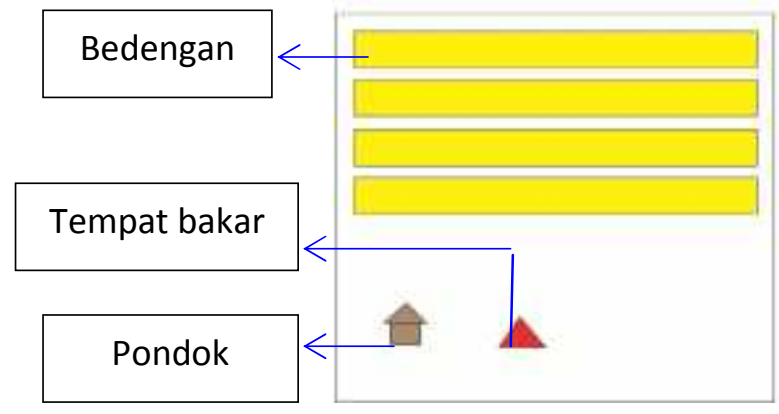

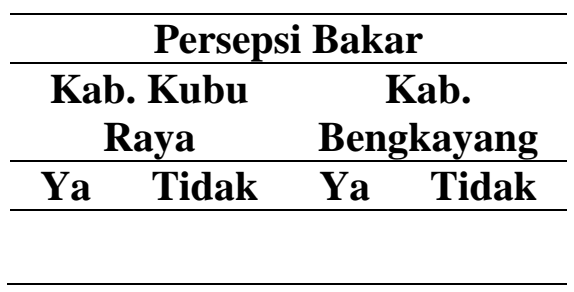

Gambar 5. Pola Bakar Lahan pada Persiapan Lahan untuk Tanaman Palawija (Jagung) 


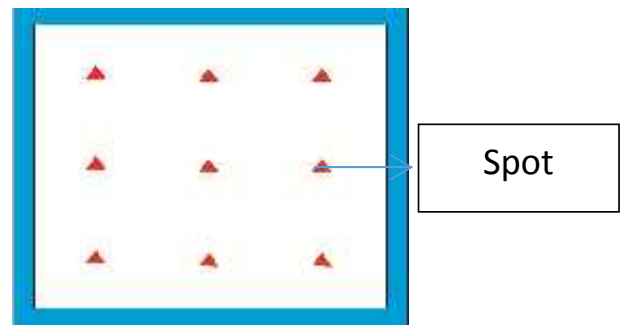

\begin{tabular}{|c|c|}
\hline \multicolumn{2}{|c|}{ Persepsi Bakar } \\
\hline $\begin{array}{l}\text { Kab. Kubu } \\
\text { Raya }\end{array}$ & $\begin{array}{c}\text { Kab. } \\
\text { Bengkayang }\end{array}$ \\
\hline Tidak & Tidak \\
\hline
\end{tabular}

Gambar 6. Pola Bakar Lahan pada Persiapan Lahan untuk Tanaman Palawija (Jagung)

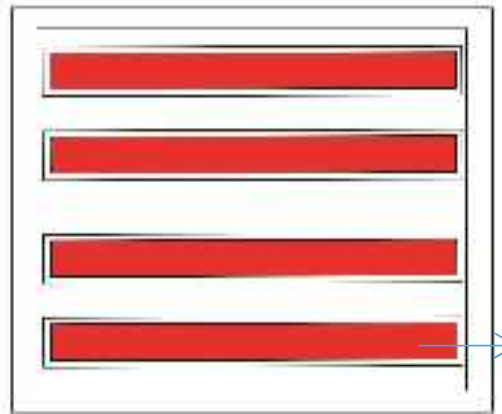

Bedengan tempat pembakaran

Gambar 7. Pola Bakar Lahan pada Persiapan Lahan untuk Tanaman Palawija (Jagung)

\section{c. Pola Bakar, Waktu Bakar dan Persepsi Bakar Tanaman Hortikultura}

Pada dasarnya terdapat perbedaan pola pembakaran yang dilakukan pada tanaman hortikultura, berdasarkan penelitian ini didapatkan 5 (lima) pola pembakaran petani hortikultura.

Pertama, pola pembakaran dengan membuat pondok abu dimulai dengan kegiatan vegetasi ditebas, dikumpulkan, dibakar selanjutnya abu sisa pembakaran disimpan dalam pondok untuk menghindari terkena hujan, kemudian abu disebar ke lahan sebelum tanam. Persepsi petani dalam perilaku pembakaran yang dilakukan dengan cara ini tidak merupakan wujud dari kegiatan pembakaran lahan seperti tergambar pada Gambar 8.

Kedua, pola pembakaran hamparan dengan cara membuat sekat bakar dibuat mengelilingi lahan selanjutnya vegetasi ditebas, kemudian dibakar secara merata dalam pengawasan. Persepsi petani dalam perilaku pembakaran yang dilakukan dengan cara ini merupakan wujud dari kegiatan pembakaran lahan seperti tergambar pada Gambar 9.

Ketiga, pola pembakaran lahan pola spot spot dengan cara vegetasi ditebas, dikumpulkan spot dibeberapa tempat, kemudian dibakar. Persepsi petani dalam perilaku pembakaran yang dilakukan dengan cara ini merupakan wujud dari kegiatan pembakaran lahan seperti tergambar pada Gambar 10.

Keempat, pola pembakaran diatas bedengan dengan cara gulma dan limbah tanaman ditebas selanjutnya dikumpulkan di atas bedengan, kemudian dibakar. Persepsi petani dalam perilaku pembakaran yang dilakukan dengan cara ini merupakan bukan/tidak wujud dari kegiatan pembakaran lahan seperti tergambar pada Gambar 11.

Kelima, pola pembakaran panduk dengan cara gulma disemprot, kemudian dikumpulkan dan dibakar/dipanduk di pinggir lahan.Persepsi petani dalam perilaku pembakaran yang dilakukan dengan cara ini merupakan bukan/tidak wujud dari kegiatan pembakaran lahan seperti tergambar pada Gambar 12.

Secara keseluruhan berdasarkan pola bakar yang dilakukan untuk waktu bakar hortikultura memiliki perbedaan antar tanaman antara lain untuk tanaman nanas yakni 
biasanya dilakukan $1 \mathrm{x}$ bakar pada bulan Februari hanya pada saat persiapan, sedangkan kacang panjang dilakukan 3x masa pembakaran pada bulan Februari, Juli dan November dan 3x di bulan Februari, Juni dan Oktober untuk penyiangan gulma. Sedangkan untuk tanaman mentimun dilakukan $3 x$ bakar pada bulan Februari, Juli dan Oktober untuk persiapan lahan dan 3x di bulan Februari, Juni dan Oktober untuk penyiangan gulma.

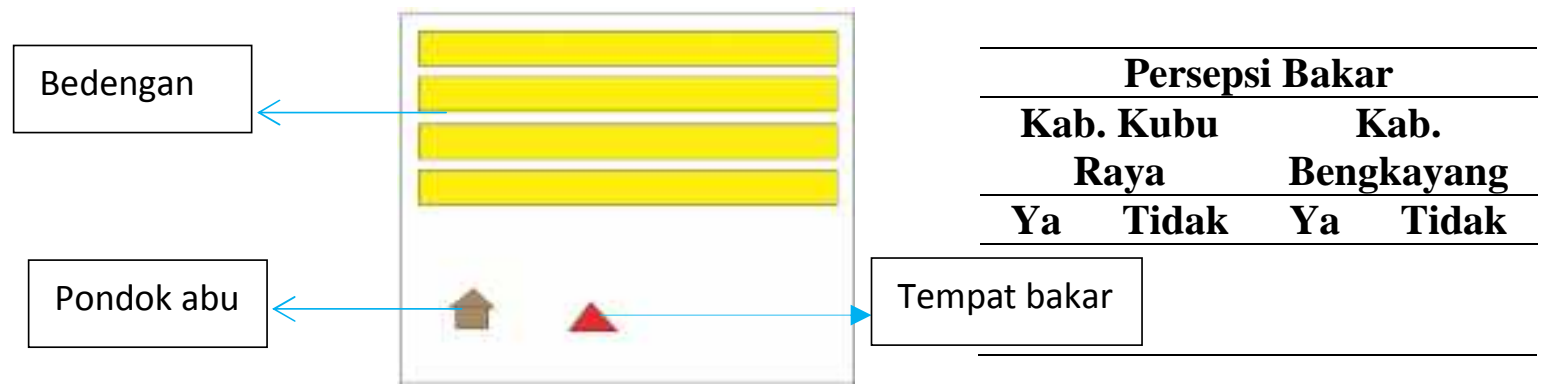

Gambar 8. Pola Bakar Lahan pada Persiapan Lahan untuk Tanaman Hortikultura

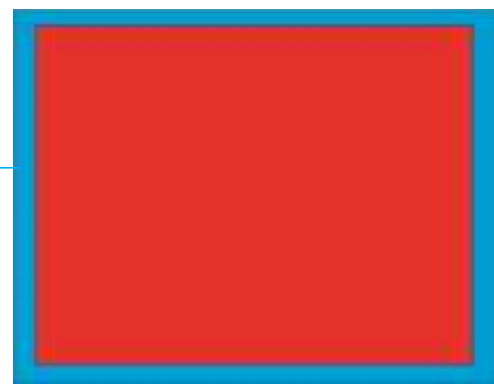

\begin{tabular}{|c|c|c|}
\hline \multicolumn{3}{|c|}{ Persepsi Bakar } \\
\hline $\begin{array}{c}\text { Kab. Kubu } \\
\text { Raya }\end{array}$ & & $\begin{array}{l}\text { ab. } \\
\text { kayang }\end{array}$ \\
\hline Tidak & Ya & Tidak \\
\hline
\end{tabular}

Gambar 9. Pola Bakar Lahan pada Persiapan Lahan untuk Tanaman Hortikultura

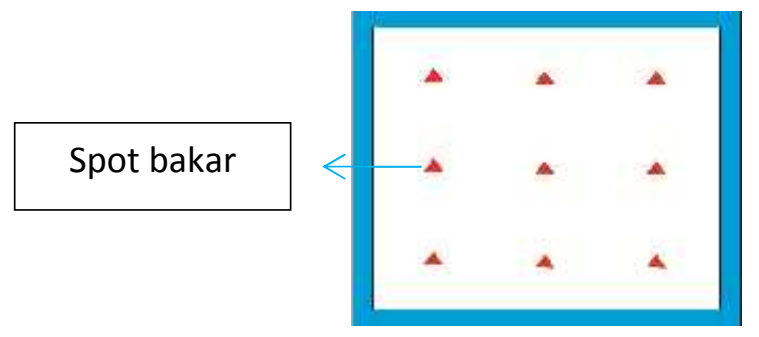

\begin{tabular}{|c|c|}
\hline \multicolumn{2}{|c|}{ Persepsi Bakar } \\
\hline $\begin{array}{c}\text { Kab. Kubu } \\
\text { Raya }\end{array}$ & $\begin{array}{c}\text { Kab. } \\
\text { Bengkayang }\end{array}$ \\
\hline Tidak & Tidak \\
\hline
\end{tabular}

Gambar 10. Pola Bakar Lahan pada Persiapan Lahan untuk Tanaman Hortikultura

Bedengan tempat pembakaran

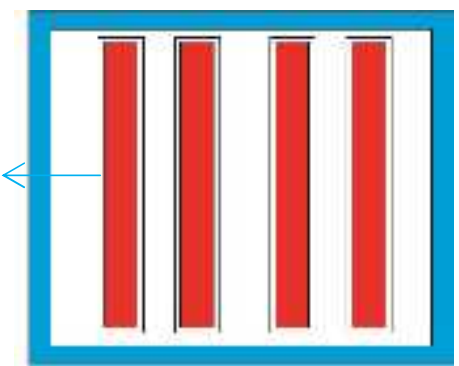

\begin{tabular}{|c|c|}
\hline \multicolumn{2}{|c|}{ Persepsi Bakar } \\
\hline $\begin{array}{l}\text { Kab. Kubu } \\
\text { Raya }\end{array}$ & $\begin{array}{c}\text { Kab. } \\
\text { Bengkayang }\end{array}$ \\
\hline Tidak & Tidak \\
\hline
\end{tabular}

Gambar 11. Pola Bakar Lahan pada Persiapan Lahan untuk Tanaman Hortikultura 


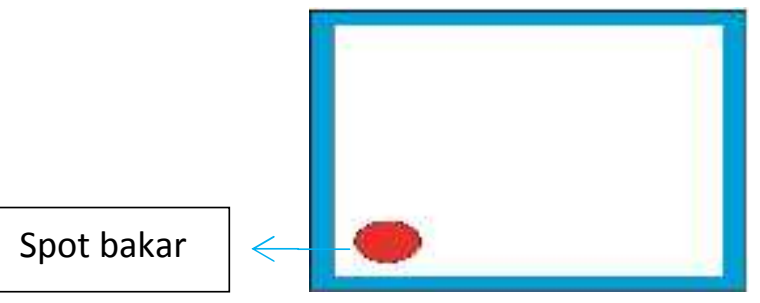

\begin{tabular}{|c|c|}
\hline \multicolumn{2}{|c|}{ Persepsi Bakar } \\
\hline $\begin{array}{c}\text { Kab. Kubu } \\
\text { Raya }\end{array}$ & $\begin{array}{c}\text { Kab. } \\
\text { Bengkayang }\end{array}$ \\
\hline Tidak & Tidak \\
\hline
\end{tabular}

Gambar 12. Pola Bakar Lahan pada Pemeliharaan dan Pascapanen Untuk Tanaman Hortikultura

\section{d. Pola Bakar, Waktu Bakar dan Persepsi Bakar Tanaman Tahunan}

Pada dasarnya terdapat perbedaan pola pembakaran yang dilakukan pada tanaman hortikultura, berdasarkan penelitian ini didapatkan 5 (lima) pola pembakaran petani tanaman tahunan.

Pertama, pola pembakaran hamparan dengan cara sekat bakar dibuat mengelilingi lahan kemudian vegetasi ditebas, selanjutnya dibakar secara merata dalam pengawasan. Persepsi petani dalam perilaku pembakaran yang dilakukan dengan metode hamparan merupakan wujud dari kegiatan pembakaran lahan seperti tergambar pada Gambar 13.

Kedua, pola pembakaran pada tanaman tahunan jenis kebun sawit dimulai pada saat pembukaan lahan dengan cara semak, pohon dan ranting yang ditebas/ditebang dikumpulkan dan ditumpuk secara spot-spot lalu dibakar. Persepsi petani dalam perilaku pembakaran yang dilakukan dengan cara ini merupakan wujud dari kegiatan pembakaran lahan seperti tergambar pada Gambar 14.

Ketiga, pola pembakaran lahan untuk lahan karet/kopi dengan cara gulma, rerumputan ditebas, kemudian dikumpulkan diantara sela-sela tanaman karet/kopi, selanjutnya gulma dan rerumputan tersebut dibakar. persepsi petani kopi dalam perilaku pembakaran yang dilakukan dengan cara ini merupakan bukan/tidak menjadi bagian dari kegiatan pembakaran lahan seperti tergambar pada Gambar 15.

Keempat, pola pembakaran lahan karet dengan cara semak ditebas, dibiarkan beberapa hari hingga kering, kemudian dibakar secara blok-blok, pola pembakaran, yaitu ditumpuk memanjang dengan I = 1,5 m. Persepsi petani karet dalam perilaku pembakaran yang dilakukan dengan cara ini bagi mereka merupakan bukan/tidak wujud dari kegiatan pembakaran lahan seperti tergambar pada Gambar 16.

Kelima, pola pembakaran pada lahan karet dengan cara semak ditebas, dibiarkan beberapa hari hingga kering; kemudian ditumpuk di luar areal tanam (pepohonan) kemudian dibakar Persepsi petani karet dalam perilaku pembakaran yang dilakukan dengan cara ini bagi mereka bukan/tidak wujud dari kegiatan pembakaran lahan seperti tergambar pada Gambar 17.

Secara keseluruhan untuk waktu bakar tanaman tahunan memiliki perbedaan antar tanaman antara lain untuk tanaman karet yakni biasanya dilakukan 1x bakar pada bulan Maret untuk persiapan lahan dan 1 kali bakar pada bulan Januari. Selanjutnya pada kelapa sawit melakukan pembakaran hanya 1 kali yakni pada bulan Februari untuk persiapan lahan dan $1 x$ untuk penyiangan gulma pada bulan Januari. Pada tanaman kopi juga hanya melakukan 1x bakar saat persiapan lahan pada bulan April dan 1x bakar pada saat penyiangan gulma pada bulan Januari. 


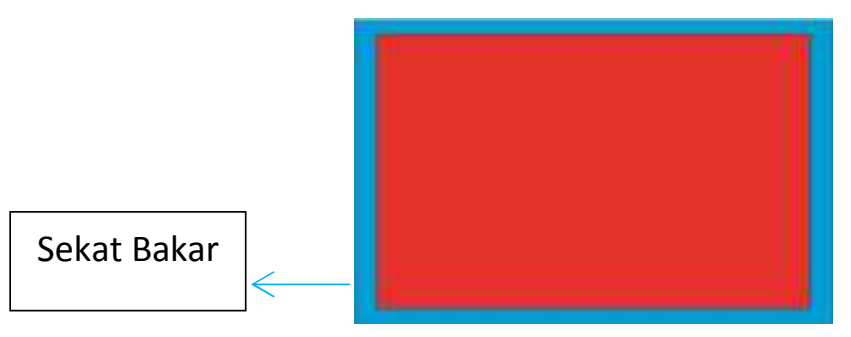

\begin{tabular}{|c|c|c|}
\hline \multicolumn{3}{|c|}{ Persepsi Bakar } \\
\hline $\begin{array}{c}\text { Kab. Kubu } \\
\text { Raya }\end{array}$ & 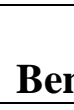 & $\begin{array}{l}\text { ab. } \\
\text { zayang }\end{array}$ \\
\hline Tidak & Ya & Tidak \\
\hline$\sqrt{ }$ & & \\
\hline
\end{tabular}

Gambar 13. Pola Bakar Lahan pada Persiapan Lahan untuk Tanaman Tahunan

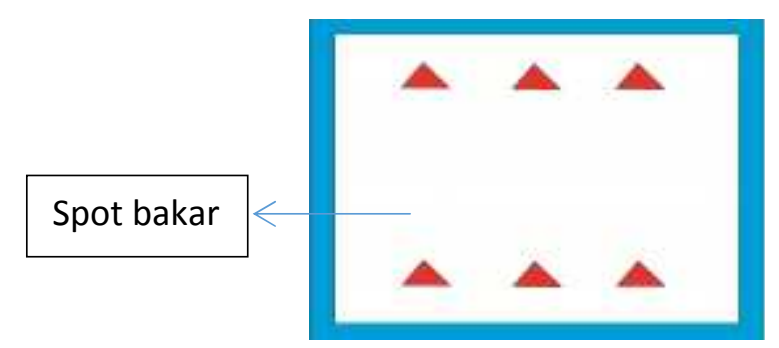

\begin{tabular}{|c|c|}
\hline \multicolumn{2}{|c|}{ Persepsi Bakar } \\
\hline $\begin{array}{c}\text { Kab. Kubu } \\
\text { Raya }\end{array}$ & $\begin{array}{c}\text { Kab. } \\
\text { Bengkayang }\end{array}$ \\
\hline Tidak & Tidak \\
\hline$\sqrt{ }$ & $\sqrt{ }$ \\
\hline
\end{tabular}

Gambar 14. Pola Bakar Lahan pada Persiapan Lahan untuk Tanaman Tahunan

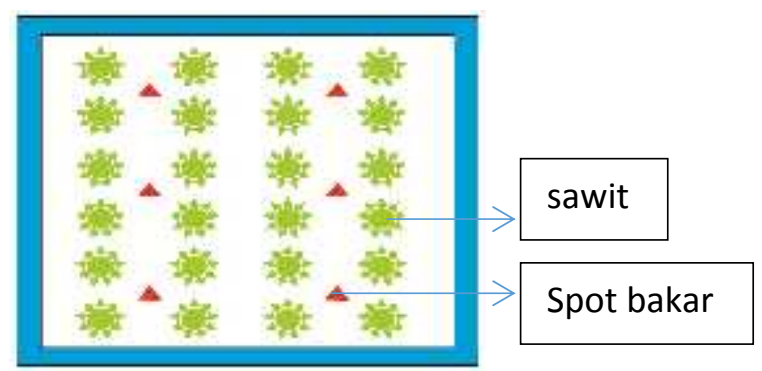

\begin{tabular}{|c|c|}
\hline \multicolumn{2}{|c|}{ Persepsi Bakar } \\
\hline $\begin{array}{c}\text { Kab. Kubu } \\
\text { Raya }\end{array}$ & $\begin{array}{c}\text { Kab. } \\
\text { Bengkayang }\end{array}$ \\
\hline Tidak & Tidak \\
\hline
\end{tabular}

Gambar 15. Pola Bakar Lahan pada Pemeliharaan Tanaman (penyiangan gulma) untuk Tanaman Tahunan

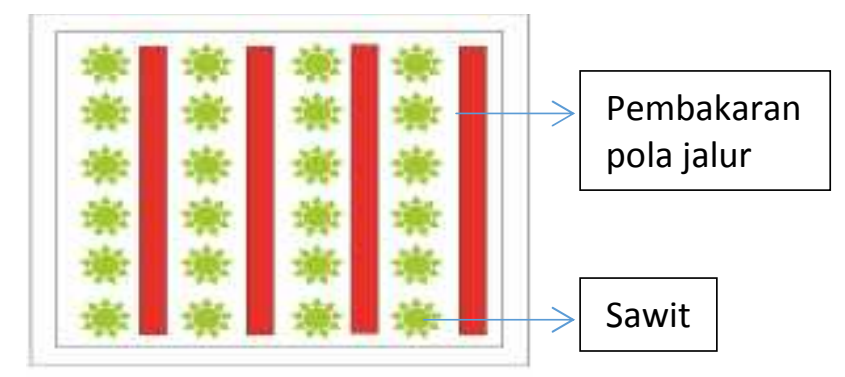

\begin{tabular}{cccc}
\hline \multicolumn{2}{c}{ Persepsi Bakar } \\
\hline $\begin{array}{c}\text { Kab. Kubu } \\
\text { Raya }\end{array}$ & \multicolumn{2}{c}{ Kab. } \\
Bengkayang
\end{tabular}

Gambar 16. Pola Bakar Lahan pada Pemeliharaan Tanaman (penyiangan gulma) untuk Tanaman Tahunan 


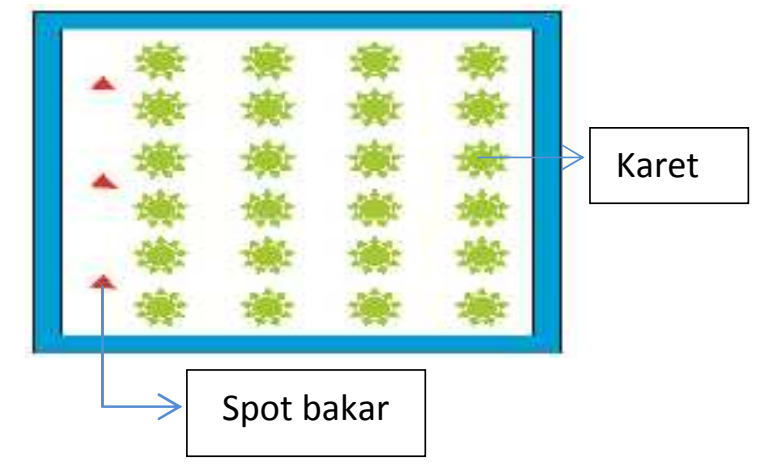

\begin{tabular}{cccc}
\hline \multicolumn{2}{c}{ Persepsi Bakar } \\
\hline $\begin{array}{c}\text { Kab. Kubu } \\
\text { Raya }\end{array}$ & \multicolumn{2}{c}{ Kab. } \\
Bengkayang
\end{tabular}

Gambar 17. Pola Bakar Lahan pada Pemeliharaan Tanaman (penyiangan gulma) untuk Tanaman Tahunan

\section{KESIMPULAN}

1. Terdapat hubungan antara tujuan membakar (membuka lahan dan memberantas gulma) dengan jumlah penduduk.

2. Tidak terdapat hubungan antara tujuan membakar lahan terhadap perilaku pembakaran lahan terkait dengan jenis tanaman utama yang diusahakan dan terdapat

3. Terdapat hubungan korelasi antara densitas hotspot dengan densitas pertanian lahan kering dan semak, desitas belukar/rawa, desitas rawa, densitas perkebunan dan desitas tanah terbuka.

4. Pola bakar yang dilakukan untuk petani padi, palawija, hortikultura dan tahunan hanya dilakukan $1 x$ pada persiapan lahan dan pemberantasan gulma dengan pola pembakaran yang dilakukan dengan metode hamparan,spot-spot, diatas bedengan dan pondok abu. Adapun persepsi petani kegiatan pembakaran dengan cara hamparan dan spot-spot menurut mereka merupakan bagian dari kegian pembakaran lahan sedangkan pola bakar dengan membuat bedengan dan pondok abu menurut persepsi mereka tidak menjadi bagian dari kegiatan pembakaran.

\section{SARAN}

1. Perlu dilakukan penelitian lanjutan terkait dampak ekologis, sosial dan ekonomi dari berbagai tipe pola dari aktivitas pembakaran yang dilakukan masyarakat di Kabupaten Kubu Raya dan Kabupaten Bengkayang

2. Perlu ditinjau kembali materi penyuluhan pertanian tentang persepsi bakar pada lahan usahatani

3. Perlu kembali upaya pencegahan dari instansi terkait pengendalian kebakaran hutan dan lahan sesuai dengan fakta persepsi dan pola bakar masyarakat.

Ucapan Terima Kasih :

Kami mengucapkan terima kasih kepada Kementerian Kehutanan dan JICA terutama perwakilan dari Direktur Pengendalian Kebakaran Hutan, Kepala Balai Konservasi Sumber Daya Alam Kalbar serta Chief Advisor FCP/JICA atas saran dan bantuannya. Kami juga berterima kasih kepada pemerintah daerah Kabupaten Bengkayang dan Kubu Raya atas bantuan langsung dan kerjasamanya di tingkat lokal dan lapangan. Kami juga 
sangat menghargai partisipasi dari berbagai pihak yang sudah memberikan kontribusi selama penelitian ini berlangsung yang namanya tidak dapat kami sebutkan satu persatu termasuk anggota Tim Pendamping Desa Pencegahan Kebakaran Hutan dan Lahan dan warga desa di desa sasaran di Kabupaten Bengkayang dan Kabupaten Kubu Raya.

\section{DAFTAR PUSTAKA}

Abdullah, M.J., M.R. Ibrahim, \& A.R. Abdul Rahim. 2002. The influence of forest fire in Peninsular Malaysia: History, root causes, prevention, and control. Makalah disajikan pada Workshop on Prevention and Control of Fire in Peatlands, 19-21 March 2002, Kuala Lumpur, Malaysia, 14 h.

Leiwakabessy,F.M. dan M.Wahjudin.1979. Ketebalan gambut dan produksi padi. Proseding Simposium III. Pengembangan Daerah Pasang Surut di Indonesia. Palembang 5 - 9 Februari 1979.

Rajaguguk,B. dan B. Setiadi.1989. Strategi pemanfaatan gambut di Indonesia kasus pertanian. Seminar tanah gambut untuk perluasan pertanian. Fak. Pertanian UISU. Medan, 1989

Sagiman, S. 2001. Peningkatan produksi kelelai di tanah gambut melalui inokulasi Bradyrhizobium japonicum asal tanah gambut dan pemanfaatan bahan ameliorant (lumpur dan kapur). Disertasi Doktor Program Pasca Sarjana IPB.

Setiadi.B. 1996. Tehnologi pemanfaatan lahan gambut untuk pertanian. Seminar pengembangan tehnologi berwawasan lingkungan untuk pertanian pada lahan gambut. Dalam rangka peringatan Dies Natalis ke 33 IPB. Bogor, 26 Sept. 1996.

Singarimbun, Masri dan Sofian Effendi. 1995. Metode Penelitian Survey. LP3ES, Yogyakarta.

Subagyo, H., DS. Marsoedi, dan A.S. Karama.1996. Prospek pengembangan lahan gambut untuk pertanian; Seminar Pengembangan Tehnologi Berwawasan Lingkungan Untuk Pertanian Pada Lahan Gambut. Dalam rangka peringatan Dies Natalis ke 33 IPB. Bogor, 26 Sept. 1996

Sugiyono. 2004. Metode Penelitian Praktis. Penerbit : Alfabeta, Bandung.

Umar, Husein. 2000, Metode Penelitian Untuk Skripsi dan Thesis Bisnis, PT. Raja Grafindo,Jakarta 